\title{
Measuring the power of parties within US Government from 1993 to 2018: New key variables
}

Matteo Laruffa

\section{(2) OpenEdition \\ Journals}

Electronic version

URL: https://journals.openedition.org/ejas/15928

DOI: 10.4000/ejas. 15928

ISSN: 1991-9336

Publisher

European Association for American Studies

\section{Electronic reference}

Matteo Laruffa, "Measuring the power of parties within US Government from 1993 to 2018: New key variables", European journal of American studies [Online], 15-2 | 2020, Online since 23 June 2020,

connection on 08 July 2021. URL: http://journals.openedition.org/ejas/15928 ; DOI: https://doi.org/

10.4000/ejas. 15928

This text was automatically generated on 8 July 2021.

Creative Commons License 


\title{
Measuring the power of parties within US Government from 1993 to 2018: New key variables
}

\author{
Matteo Laruffa
}

\section{Introduction}

1 Recalling the common traits of many theories since the Ancient Greece, Wolfgang Merkel mentions the thought of Plato, Aristotle, Hobbes, Tocqueville, Marx and Weber to remind us that "political theory has posited from the outset that democracy is inconceivable without crisis." ${ }^{1}$ As with many phenomena in political science, ones relating to democracies in crisis have captured the imagination of a diverse group of scholars from Classical Greece to our days. In the ancient world, Aristotle was among the first authors to discuss it, while two centuries ago, the French political scientist Alexis de Tocqueville furthered the topic with a focus on the risks for representative institutions. One of Alexis de Tocqueville's lessons is actually very important for our times and draws striking relevance to the contemporary era. As the author of the famous book Democracy in America realized, new forms of despotism can develop themselves from the dysfunctions of representative democracy. ${ }^{2}$ Indeed, past studies consider the crisis of democracy as an inevitable circumstance which can occur in this political regime.

2 Recent political changes in European and other western countries suggest that democracy is in crisis where emerging leaderships use the democratic game against democracy itself. That is to say, to put the definition of crisis of democracy in a nutshell, democracy is in crisis when it allows to its enemies to attack its institutions of defense from within. This fundamental change manifests in many risks for democracy, where its institutions are attacked from elected leaders and parties in order to dismantle their fundamental principles as well as constitutional guarantees. 
3 In time of risks for democracy questions arise of how to defend its institutions, and above all, if parties balance and limit the power of the incumbent or not. That is why, our study concerns a selected group of variables on American parties and the U.S. Government, with the aim to offer a structured case-study approach during the last quarter century.

\section{Political parties and the check-and-balance system}

4 Adam Przeworski's words greatly influenced this part of the research, when he wrote that: "We tend to confuse the ideals of founders for a description of really existing institutions. This ideological veil deforms our understanding and our evaluations." 3 Contrary to the mainstream vision of the balance of power as based on the barriers between executive and legislative, this research investigates the idea of limits to political power of the incumbent from a different perspective which rejects what $\mathrm{J}$. Madison called "the purity of the theory." In the past, those who wanted to divide the political power, tried to delve with it imagining a horizontal separation based on giving different functions (for instance, legislative and executive ones) to different institutions. In some cases, this level of division could be increased by a vertical separation between central government and local ones. As Daryl J. Levinson and Richard H. Pildes rightly noted, political competition changed the separation of powers system in the American democracy, and we would not hesitate to add that it is possible to note similar changes in almost all western democracies. Levinson and Pildes argued that: "Just as parties can create the conditions necessary for inter-branch competition to emerge, they can also submerge competition by effectively reuniting the branches." 5

With this in mind, it seems reasonable to assume that against the expectations of architects of constitutional design, beyond a conventional idea of the division of powers between legislative and executive, these two branches are ever less competitive one another, as they work together and share most of their functions. One of the most telling indications that these branches are working as a single political decision-maker is that usually the executive proposes and the legislative disposes. For example, in the processes to approve laws and policies. Hence, their actions and functions complete one another, as parts of a single process where the power is handled by some groups of people within institutions, rather than by one institution against the other. It is not unrealistic to reshape our analytical perspective on how the political power has developed itself in the last century, in order to include in the idea of balance of power the actual behavior of executive and legislative branches as well as of the parties which compete in the political decision-making process. This idea reflects the reality of many democracies in a pragmatic way. For example, with reference to the U.S., Francis Fukuyama recently argued: "The normal functioning of our check-and-balance system has been dependent on some degree of cooperation between the parties. It has seized up in recent years as the parties have become more polarized and ideological." ${ }^{6}$ The de facto arrangement of political power becomes the hallmark of a new realist view of democratic institutions.

Let the issue be phrased as follows: in presidential systems where politics is polarized, the legislative has used powers to check only on presidents of the opposite parties, while these powers are substantially not exercised in other cases. Under these circumstances, presidential systems do not function very differently from the 
parliamentary ones. Similarly, in parliamentary systems, it is very unusual that the legislative votes against the executive (for example the parliament approves a motion of no confidence), because the majority supports the government, and in most of parliamentary democracies, a motion of no confidence implies also the end of the legislature. That is to say that members of parliament avoid to simply be forced to leave their own office and job. As Leonardo Morlino and Wojciech Sadurski stress: "the parliamentary majority supports the government without controlling it or it can be actually controlled by the government." In a few words, it is not just the life of the government that depends on the parliament, but also the life of the parliament depending on that of the government. Finally, if we analyze the actual behavior of the two branches, we discover that things are not different in many semi-presidential systems as well. In this sense, the balance of power and the division of power are not effective.

7 Let see some examples and data confirming these claims on this connection of power in the hand of the majority. As an example, we can observe the disagreement between executive and legislative in the United States by monitoring the voting behavior of the majority within Congress on the president's position via roll call voting in terms of "vote concurrence." This measure calculates the number of times the majority within Congress voted with the president's position on roll call votes. Although this is not the only possible proxy, it might be plausible to use this one. Let consider the data (Source: The American Presidency Project) related to the last three presidents before Donald Trump. During the years of Bill Clinton's presidency, the vote concurrence was $86,4 \%$, when the Democratic Party held the majority of the Congress (this is an average of vote concurrence before the incumbent party lost the majority). It declined to $48,6 \%$ when the majority changed (this is an average of vote concurrence after the opposition became the majority in Congress during the period of divided government). In the first period of Clinton's administration, the majority controlled both the branches. Indeed, the legislative and executive did not perform like competitive branches or anyway they acted in agreement almost 9 out of 10 times. During George W. Bush's presidency, similar evidence show that the two branches work as it would be one single deciding institution in more than 8 cases out of 10 before the majority changed, when vote concurrence declined from $80,78 \%$, to $32,3 \%$. Finally, when Barack Obama was president, he had $91,25 \%$ of support when the majority was Democrat, and $55,8 \%$ (this last average is related to the available data until 2013) after the Republicans controlled again the Congress. This means that, in the first period of the Obama administration, executive and legislative decided together more than 9 times out of $10 .{ }^{8}$

8 In these cases, the relation between executive and legislative changed when the majority in the Congress changed, and this happened under each president. As obvious as this evidence might be in the perspective of the alternation of united or divided governments occurring election by election, it is not obvious what they demonstrate with regards to perspective of the mainstream theory of division of power. Basically, in a system like the U.S., the division of power between executive and legislative exists and works just when the division within the political power exists and works, producing effective dissent and checks. This example is more relevant because it concerns the American case. Namely, the constitutional system of division of powers that is traditionally seen as perfect. Albeit it is well known as a mechanism of constitutional checks and balances without a flaw, these data tell us that the reality of the limit to the political power in the United States is very different. Because the same 
party does not control nor engender any form of dissent against representatives of its own group, also when they sit in or chair other institutions. Indeed, when one party or a coalition controls the political branches, then there are no incentives to check eachothers. If the majority dominates the political power, then the barriers between executive and legislative dissolve, and while a "dominated" decision-making process emerges, the opposition runs into the condition of the spectator as an actor confined to be unable to counterbalance the majority.

This is more relevant if we considered the most disregarded part of the doctrine of the separation of power, which M. J. C. Vile described as the "separation of persons." According to M. J. C. Vile, the three branches of government should be composed of quite separate and distinct groups of people, with no overlapping membership. ${ }^{9}$ Therefore, we can say that the relation between executive and legislative depends on the relation between majority and opposition. Despite optimism regarding the Enlightenment theories of the division of power, a realist point of view tells us that checks and balances work just if this division is first of all within the political power, rather than between powers, because the second is simply impossible without the first. This is the conditio sine qua non that makes checks and balances effective.

Another example of the connection between executive and legislative, which becomes an addition of powers in the hands of the majority, is possible because the use of the delegation of legislative functions to the executive. According to David Epstein and Sharyn O'Halloran, in the U.S., delegation toward the Executive Office of the President and executive agencies is more common and frequent under unified government, while delegation gives more often new functions to independent agencies under a divided government. ${ }^{10}$ As would be expected, we can say in other words, that Epstein and O'Halloran's research shows how the Congress more likely votes to delegate discretion to the executive when it is controlled by the same party, while the Congress does it significantly less and with more constraints, when the opposite party holds the executive. Let focus on some paradigmatic examples in which the majority uses both executive and legislative powers in the relation with the opposition. John D. Huber suggested that in a parliamentary system, in a confidence vote procedure, the government is the first-mover which does a take-it-or-leave-it policy proposal. ${ }^{11}$ Hence, in most parliamentary democracies, in Michael Laver and Kenneth A. Shepsle's terms, everyone outside the executive does not have a significant impact on the process of legislation. ${ }^{12}$ Giovanni Sartori described into details other cases like that one of "governing by legislating" where different procedures force the legislative to be under the "take or leave" of the executive, with injunctions that allow little, if any, room for feedback and mutual interaction. ${ }^{13}$

11 The division of powers between executive and legislative effectively exists when the political power is not wholly concentrated in one party, and hence, the majority controls just one of these branches. Indeed, Fukuyama affirms that: "Institutional checks in a political system are not, after all, like physical barriers to action. They work only to the extent that the people who constitute the system agree to abide by them, and this in turn is a function of politics." ${ }^{14}$

12 From this latter perspective, the greatest challenge that emerges is not to look how the institutions are divided between themselves, but how actors divide and unite themselves inside and across the "walls" of the institutions. Leaving aside the classic idea of the Roman principle "divide et impera" (divide and rule), the real political life has 
been shaped by the opposite principle "unite et impera" (unite and rule) that radically overturns the traditional vision drives political actors towards the coordination within institutions. When these institutions are united under a single party which can monopolize the decisions, the political power of the incumbents becomes a mean of imposition without opposition. Particularly noteworthy is to emphasize that many democratic institutional systems are under the risk of being politically dominated, where the boundaries between powers are not those ones of executive and legislative competing one another, as written on the paper, but just those ones between majority and opposition, and the first can divest the second of its purpose with various silencing strategies where legal procedures are used as political weapons. The two broad conditions - the substantial reduction of checks between executive and legislative, and the trend towards the unification of these institutions into a single political decisionmaker - had important consequences that need to be studied well beyond the ideal barriers existing on parchment or in our theoretical models of the balance of power. Political parties enter across institutions, as well as the horizontal and vertical separation of powers. Therefore, the line of division of power to be considered is not anymore that one between legislative and executive, it has to be a line of division in the political power that we can observe from monitoring the patterns of behavior between majority and opposition. In this sense, it is more useful to think that the lines that unite the power, rather than those ones which divide it, are the new crucial targets to observe for pursuing our research goals.

This suggests, on a broader canvas, that we need to venture beyond what James Madison called "parchment barriers" and follow the power where it goes. ${ }^{15}$

\section{Monitoring political and institutional factors}

"The American Constitution, then, was born in crisis and tested in crisis." -

SANFORD LEVINSON, JACK M. BALKIN, Constitutional Crises

Ariefly mentioned in the introduction, when in crisis, democracies are under attack and their defenses became the target of strategies that the incumbents try to accomplish in order to silence the opposition and push it out of decisions, politicize institutions of vigilance and dismantle constitutional guarantees. The final aim of this attack is to enlarge the power of the incumbents and convert institutions into a mechanism of plebiscitary self-perpetuation of consensus. This strategy of attack can impact in different ways on democracy depending on the institutional strength of the regime. The more the defenses of a democracy are, the stronger a democracy is. When the antidemocratic strategy faces strong institutional defenses, a struggle for democracy to stay alive begins. Our central question, therefore, is why some democracies resist, while others experienced one or more transformations of their institutions which leave them weak and paralyzed in the hands of the incumbents. The consequences of this confrontation between opposite forces can resemble one of the four dynamics between the reaction of institutions and their inertia:
1. Institutional containment;
2. Institutional resistance;
3. Institutional compliance;
4. Institutional disarmament. 

institutional disarmament can take place in order to transform the regime into a defenseless democracy. On the other hand, when its institutions react, democracy can experience a temporary condition of institutional resistance or containment. Within this framework, political parties can work in order to protect the constitutional structures of the state or follow anti-system strategies against fundamental democratic principles. A halfway situation occurs when political and independent institutions act in a substantial compliance, which consolidates the incumbents. The antidemocratic component inside the institutional system can increase without effective oppositions or counter-powers, although institutions are not de facto changed nor formally reformed. By way of illustration, the case of the U.S. shows how to calculate each variable of the Index of Institutional Strength in order to provide an empirical analysis of the changes occurred in the American institutions since November 2016, when Donald Trump was elected the $45^{\text {th }}$ President of the United States. Thomas Friedman of the New York Times recently wrote that "the biggest threat to the integrity of our democracy today is in the Oval office." ${ }^{16}$ By observing the institutional strength and the political defense of the U.S. during the last years, it is possible to say if Friedman is right or not when he accuses the President of being the main risk for the American democracy. In order to measure the institutional strength, we need to find the value of the following variables: political defense, institutional vigilance and constitutional entrenchment. of level of neutrality of the decision-making, judicial overruling of political decisions, autonomy of independent institutions, and finally, the degree to which is more easily that the constitution can be politically manipulated, that is to say, its entrenchment. In this way, we might try to characterize either the defense system as a whole, or the single institutional defenses in terms of some relevant dimensions.

The political defense is symbolized by " $p$ " and its measure is based on his difference between the number of all political decisions and those ones we can consider unilateral decisions, because the majority adopted them by circumventing the opposition. The higher the level of political defense is, the more effective the constraints on the majority are and hence the opposition is able to limit its powers and avoid it can impose unilaterally a direction to democracy. This dimension contemplates the tools that the majority can use to limit the opposition and the likelihood it actually uses them. The space of political defense calculates the exact limits the opposition poses to the majority by measuring the amount of political power of the opposition versus the majority within the political decision-making. By political power we mean: the power to decide that is wielded together by the main political institutions for the approval of laws, policies and appointments. Namely, the power of the elective institutions of the executive and legislative branches.

19 To assess the level of institutional vigilance, we selected the sub-variables whose variations could suggest the direct measure of the degree of insulation of judicial and other independent institutions from the power of incumbents. For instance, one of the sub-variables, the "diversified appointment procedures" monitors how members of each institution are appointed, and if these procedures for appointment involve many political actors from different parties. Particularly noteworthy, we consider "diversified" an appointment procedure which requires the participation of the opposition and cannot be accomplished just by the executive or members of the 
governing party or majority. That is to say if courts, tribunals and other institutions of vigilance can be easily subjugated and controlled by the majority, or their members are appointed through procedures which require the agreement between majority and opposition.

The values of these two groups of sub-variables can be aggregated in the single indicator: institutional vigilance (v), which captures the ability of judicial and independent institutions to stay independent and survive.

The last component of this index would measure the level of entrenchment of constitution (e), with the aim to assess the limit on the ruling parties to change the constitutional structure. In order to evaluate how resistant the constitution is to stand up against political attacks that threatens its integrity, it is possible to monitor some binary sub-variables.

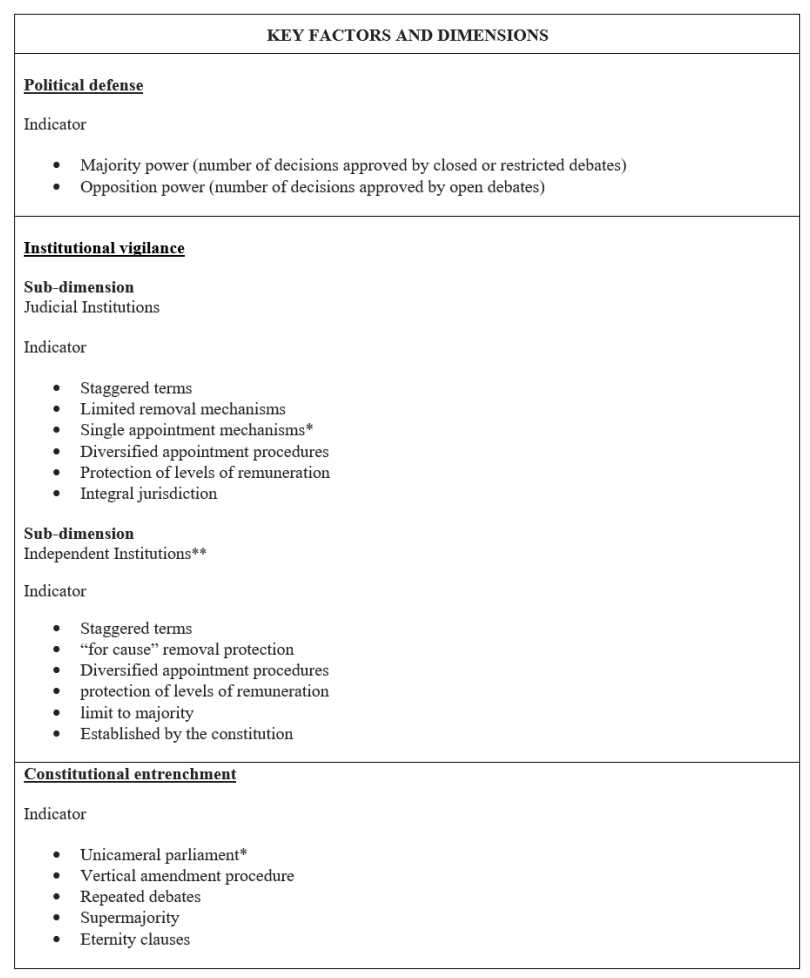

Table no. 1 - Dimensions of observation; *Scoring on these items is reversed. ${ }^{* *}$ To calculate the institutional vigilance the features coded in the second group of sub-variables should be controlled for every independent institution.

The data related to the case of the American democracy indicate the variation of institutional strength in the last decade (see Figure no. 1), with details on the current value for each single variable (see Figure no. 3). This analysis then goes on to treat the political defense and its change during the last 25 years. We limit our study over a significant period which started with the presidency of Bill Clinton until the current one of Donald Trump. The most recent data are related to January $31^{\text {st }} 2018$. 


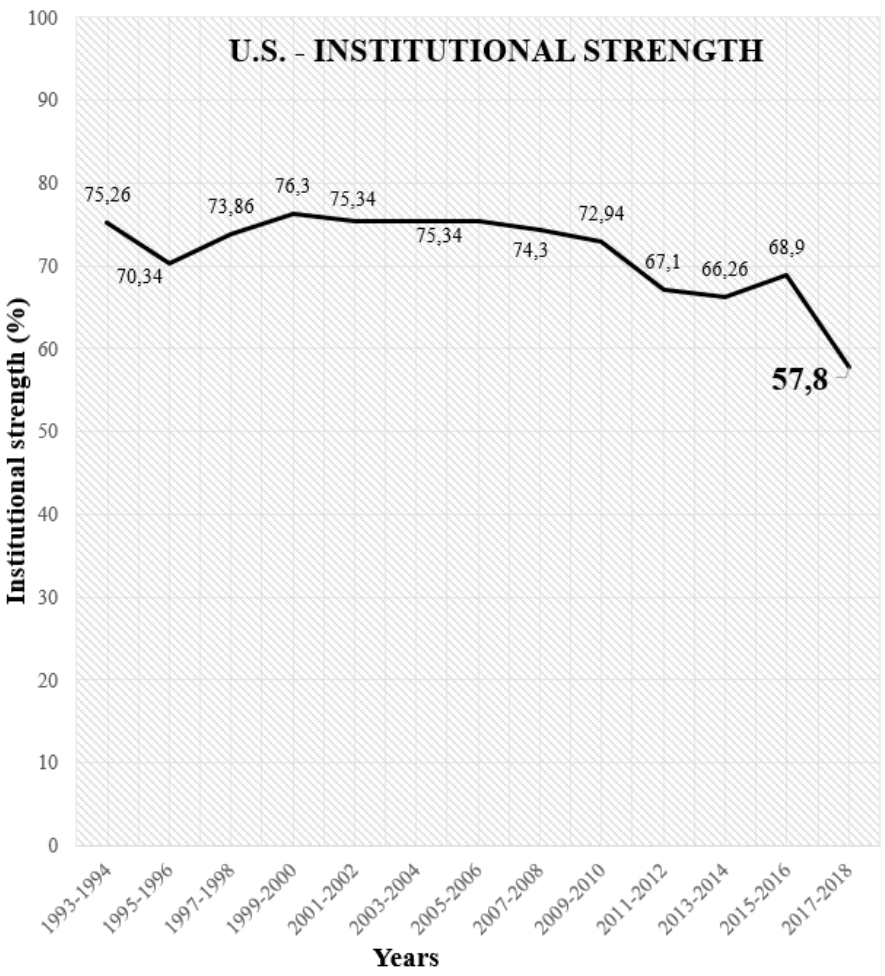

Figure no. 1 - Institutional Strength U.S. - Sources: The U.S. National Archives and Records Administration, Federal Register: laws; Gerhard Peters and John T. Woolley The American Presidency Project, 1999-2018; Bipartisan Policy Center.

$$
D S_{2017}=57.8
$$

\begin{tabular}{l|c}
\multicolumn{2}{c}{ POLITICAL DEFENSE } \\
USA $\left(1993-\mathbf{2 0 1 8}^{2}\right)$ \\
\hline Congress & Data (\%) \\
\hline $\mathbf{1 0 3}^{\text {rd }}$ & 76.5 \\
$\mathbf{1 0 4}^{\text {th }}$ & 64.2 \\
$\mathbf{1 0 5}^{\text {th }}$ & 73 \\
$\mathbf{1 0 6}^{\text {th }}$ & 79.1 \\
$\mathbf{1 0 7}^{\text {th }}$ & 76.7 \\
$\mathbf{1 0 8}^{\text {th }}$ & 76.7 \\
$\mathbf{1 0 9}^{\text {th }}$ & 76.7 \\
$\mathbf{1 1 0}^{\text {th }}$ & 74.1 \\
$\mathbf{1 1 1}^{\text {th }}$ & 70.7 \\
$\mathbf{1 1 2}^{\text {th }}$ & 56.1 \\
$\mathbf{1 1 3}^{\text {th }}$ & 54 \\
$\mathbf{1 1 4}^{\text {th }}$ & 60.7 \\
\hline $\mathbf{1 1 5}^{\text {th }}$ & $\mathbf{3 3}$ \\
\hline
\end{tabular}

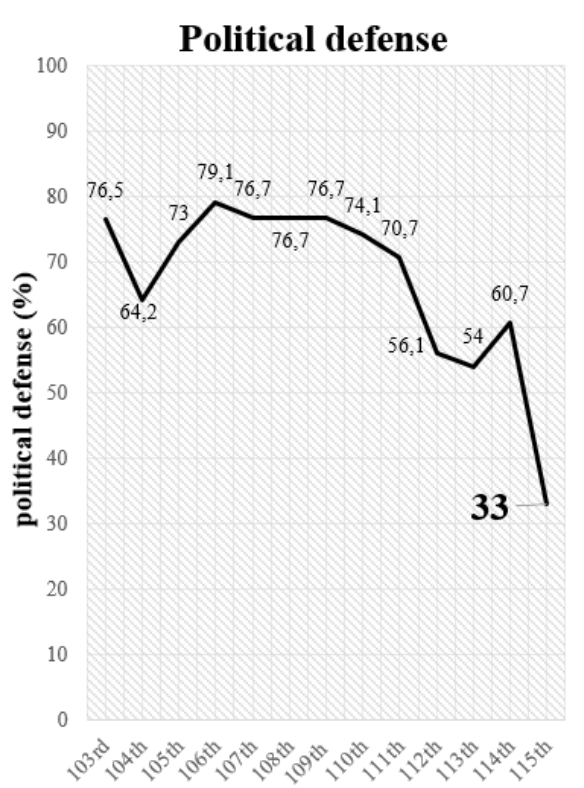

US Congress

Table no. 2 and Figure no. 2 - Note: My own calculations based on data provided by U.S. National Archives and Records Administration, Federal Register: laws; Gerhard Peters and John T. Woolley - The American Presidency Project, 1999-2018; Bipartisan Policy Center. 
back over the past 25 years, the most remarkable phenomenon is the continuity and consistency of the trend of political defense with an average value of $63.5 \%$. Interestingly, Figure no. 2 now stands at $33 \%$. Our evidence shows the infrequency of this political condition. In the last quarter of century, the level of political defense has never been so low. The first year of the Trump administration marked an absolute negative record in terms of a continuous abuse of power which has limited as never before the role of the opposition. This extremely low value represents a worrisome increase, that can be seen as abnormal, in the recourse to bypass rules by the incumbent. Hence, the majority has unilaterally imposed laws and policies in most of the time, without leaving any chance for the opposition to participate and contribute to decisions.

This is a daunting challenge for democracy. The empirical findings in this study provide a new understanding of radicalization of political elites in the U.S. More specifically, as hypothetised by S. Levitsky on the Republican Party: "The radicalization of the GOP base has generated intense partisan animosity, which has encouraged Republican politicians to deploy increasingly hardball tactics to maintain power." ${ }^{17}$

What is striking in these tables is that there are two previous periods of minimum political defense. A more complete evaluation requires also to observe other variables and to contextualize them into a wider framework which includes some information from qualitative research. However, in order to give a more accurate portrait of the real conditions of democracy in the U.S., we need to examine in depth this trend and answer to the following questions: why and when the political defense fell down in some moments of recent history of the American democracy? which are the implications of the minimum value that we see today? do these moment of low political defense represent or not a threat to democratic institutions? The first fall and rise of political defense was between 1995 and 1997 under President Clinton, when the majority of both chambers of the Congress became Republican after many decades. In a condition of division of political power, where there is not one single party controlling the key institutions of politics, the risk of an abuse by one group of politicians or one leader is almost unreal as these institutions check one another and are not controlled unilaterally. The increase of unilateral actions by the executive can be explained as the President preferred to avoid being completely eclipsed by a new rival majority. At the same time, as the value of political defense depends also on the total number of decisions approved by political institutions, in a condition of substantial division of power where opposite parties control crucial segments of the decision-making process, the productivity of these institutions can be very low. Hence, the first of these minimum values of the dataset does not represent any particularly dangerous risk for the American democracy as it resulted from a divided government.

26 This argument is certainly pertinent to remind us what said in the previous pages about the unity of political power and the danger of executive majorities. Democratic institutions are under risk to be weakened when the majority or a single party controls the entire decision-making process and abuses of the power by divesting the political opposition. Hence, the other two low values of political defense related to the $112^{\text {th }}$ Congress and the $113^{\text {th }}$ one should not concern us as they occurred in periods of divided government. The successive minimum, that accurately represents the current political conditions, is the tangible clue that democracy is under attack in the U.S. as one single party controls the whole decision-making process of democratic institutions, and as

European journal of American studies, 15-2 | 2020 
showed by empirical evidence, it proves that the majority insists to limit the opposition. The political defense under Trump is a few percentage points higher than half of that one we noted when Obama left the Oval Office. There has been an increase of the power of the majority through bypass rules of $95,92 \%$. This is the first attack we can monitor to democratic institutions, which are weaker today than before Trump got elected as president.

$$
A_{p}=+95,9 \%
$$

The following tables show one by one all the variables and their sub-variables to be added to the political defense for the aggregate measure of the Index of Institutional Strength. As there have been not any relevant reform of these institutions, nor of the constitutional amendment procedures, hence their values are considered as constant in the last 10 years.

\section{INSTITUTIONAL VIGILANCE \\ JUDICIAL INSTITUTIONS}

Supreme Court of the United States

\begin{tabular}{l|c|c}
\hline \multicolumn{1}{c|}{ SUB-VARIABLE } & YES & NO \\
\hline Staggered terms & $\checkmark$ & \\
Limited removal mechanisms & $\checkmark$ & \\
Single appointment mechanisms* & $\checkmark$ & \\
Diversified appointment procedures & & $\checkmark$ \\
Protection of levels of remuneration & $\checkmark$ & \\
Integral jurisdiction & $\sqrt{ }$ &
\end{tabular}

Table no. 3 - *Scoring on these items is reversed. Note: The cases were coded using a binary system. Source: The Constitution of the United States of America, Art. 3, 1787; Rules of the Supreme Court of the United States, 2017.

INDEPENDENT INSTITUTIONS United States Commission on Civil Rights

\begin{tabular}{l|c|c}
\hline \multicolumn{1}{c|}{ SUB-VARIABLE } & YES & NO \\
\hline Established by the constitution & & $\checkmark$ \\
Staggered terms & $\checkmark$ & \\
"for cause" removal protection & $\checkmark$ & \\
$\begin{array}{l}\text { Diversified appointment procedures } \\
\text { protection of levels of remuneration }\end{array}$ & $\checkmark$ & \\
limit to majority & $\checkmark$ & $\checkmark$
\end{tabular}

Table no. 4 - Note: The cases were coded using a binary system. Source: United States Public Laws $103^{\text {rd }}$ Congress N. 419, Civil Right Commission Amendments Act, October 25, 1994. 
Federal Communications Commission

\begin{tabular}{l|c|c}
\hline \multicolumn{1}{c|}{ SUB-VARIABLE } & YES & NO \\
\hline Established by the constitution & & $\checkmark$ \\
$\begin{array}{l}\text { Staggered terms } \\
\text { "for cause" removal protection }\end{array}$ & $\checkmark$ & \\
$\begin{array}{l}\text { Diversified appointment procedures } \\
\text { protection of levels of remuneration }\end{array}$ & & $\checkmark$ \\
limit to majority & $\checkmark$ & $\checkmark$
\end{tabular}

Table no. 5 - Note: The cases were coded using a binary system. Source: Title 47 of the Code of Federal Regulations.

Federal Election Commission

\begin{tabular}{l|c|c}
\hline \multicolumn{1}{c|}{ SUB-VARIABLE } & YES & NO \\
\hline Established by the constitution & & $\checkmark$ \\
$\begin{array}{l}\text { Staggered terms } \\
\text { "for cause" removal protection }\end{array}$ & $\checkmark$ & \\
$\begin{array}{l}\text { Diversified appointment procedures } \\
\text { protection of levels of remuneration }\end{array}$ & & $\checkmark$ \\
limit to majority & $\checkmark$ & $\checkmark$
\end{tabular}

Table no. 6 - Note: The cases were coded using a binary system. Source: Federal Election Campaign Act, Pub.L. United States Public Laws $92^{\text {nd }}$ Congress, N. 225, enacted February 7, 1972.

CONSTITUTIONAL ENTRENCHMENT

\begin{tabular}{l|c|c}
\hline \multicolumn{1}{c|}{ SUB-VARIABLE } & YES & NO \\
\hline Unicameral parliament* & & $\checkmark$ \\
Vertical amendment procedure & $\checkmark$ & \\
$\begin{array}{l}\text { Repeated debates } \\
\text { Supermajority }\end{array}$ & $\checkmark$ & $\checkmark$ \\
Eternity clauses & & $\checkmark$
\end{tabular}

Table no. 7 - Note: The cases were coded using a binary system. * ${ }^{*}$ coring on these items is reversed. Source: The Constitution of the United States of America.

Finally, as already mentioned many times in these pages, our analysis includes also some additional information and data which can provide a cross-check indicator. This mixed method of research, which emphasizes the importance of qualitative analysis, provides a complete observation of the Index of Institutional Strength. This cross-check indicator allows us to highlight the crucial cases of substantial abuses of power, which cause the reaction of non-political institutions for preserving the democratic identity of the regime. Because the developments examined here with reference to this cross- 
check are relatively recent, we cannot already draw some definitive conclusions about it.

Nevertheless, it is particularly noteworthy to stress that some of the key political decisions approved by the majority over the last year and half of Trump administration have been substantially blocked or changed by the judiciary. They reveal an essential action aimed at counterbalancing the power of the incumbents and protecting the democratic values at the bases of many American institutions and their policies.

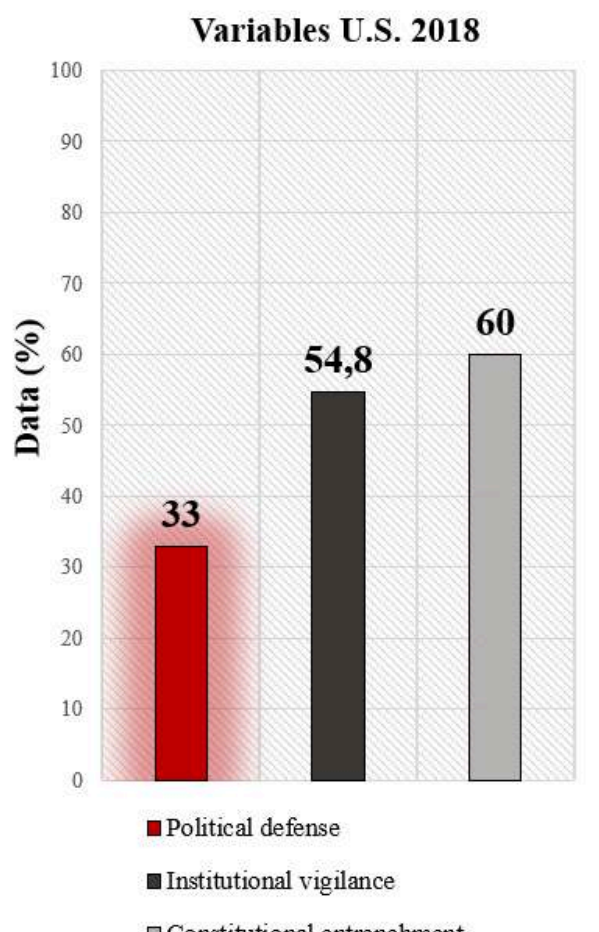

Figure no. 3

The relationship between Donald Trump and the judiciary might best be described as contentious. From the beginning of his tenure as president, he continuously criticized various criminal justice agencies such as the FBI or the CIA which of course strained the relationship.

The judiciary intervened in various crucial cases. While none yet halted the enforcement of Executive Order N. 13767 "Border Security and Immigration Enforcement Improvements" (January 25, 2017), which is famous for the project of the wall along the nearly 2,000-mile southern border of the U.S., or the Energy Independence Executive Order (Executive Order N. 13783, March 28, 2017), many others have been blocked. More generally, courts ruled against the President as never before. An example, maybe the most important, is that one of Trump's decision to end the Deferred Action for Childhood Arrivals (DACA) immigration program. Notwithstanding these remarkable examples, events may still derail this confrontation, but there are two other reasons to be confident that the institutional defenses will win the ambitions the Trump administration might have and save the American democracy.

What is important to remember about the United States judicial system is that it is set up in essentially a branch system. While the Supreme Court is the most important court in the land, having the power to overrule lower court rulings, not all legal issues are 
heard before the nine justices on the court; while the Supreme Court decides around 80 cases per year, appellate courts decide a staggering 58,000 cases annually. Thus it is the entire U.S. court system which is important to identify in its relationship with the president. Additionally, there is evidence that points to a similarly tense relationship with the courts. Most notably, Trump has accused a judge of Mexican heritage of a biased ruling against him. In addition to that, a number of courts that stopped some of his executive orders have been sharply criticized by him. However, the Supreme Court has recently upheld his travel ban, overturning the rulings of lower courts. This last example shows how the courts can limit the President's power on the one hand, but also strengthening it on the other. Overall, even though Trump might have numerous ways to indirectly influence the political orientation of the judiciary and thus turn the odds in his favor. Ultimately, though, especially the judges generally work free from political pressures and do not have to fear political retaliation by voters, politicians or the administration and thus can rule freely. This might be one of the strongest and most enduring check the American democracy has.

Firstly, the Washington community has not completely adapted to the new president. In fact, it has engaged in an unprecedented tussle with the team of Trump's most vocal supporters. That fight was won over the course of a few weeks after the more complex moments at the start of his presidency (the famous 100 days), which featured the resignation of Michael Flynn and the demise of Steve Bannon. The administration was then filled out with people chosen to mediate between the president, the Pentagon and the Security and Defense Agencies. The man who came to epitomize this new phase was the new National Security Advisor, General H.R. McMaster, who experts claim is muchloved in Washington and despised by the President. However, another interesting aspect to be observed in this regard is Trump's attitude to dismiss dissenting voices. Just to mention a few examples, it happened with James Comey (head of the FBI), Andrew McCabe (Comey's replacement), Gary Cohn (head of the National Economic Council), Rex Tillerson (Secretary of State), H.R. McMaster (national-security advisor), David Schilkin (head of Veterans Affairs). These episodes are only a few of the instances of the ongoing power struggle between President Trump and the other institutional forces which are uninterested in radical change. Secondly, elections are not just the beginning of the crisis, as they can be also its end. Indeed, as voters can give the power to antidemocratic political parties, if the incumbents do not damage the institutions, then they can be removed with new elections. As the result of the Midterm elections show, the recurring rounds of voting for renovating political institutions, resemble the flux of a continuous election in pieces, which can scale down Trump's power and definitively end the attack to the American democracy. Therefore, the future of democracy in the United States will rest also in the hands of citizens.

In summary, the American democracy is a case in which, despite unfavorable conditions of political defense and the obstinacy of Trump to act as an antidemocratic leader (for example, with continuous delegitimation of other institutions), extensive measures of vigilance and insurmountable constitutional barriers surround the incumbent. Therefore, notable constrains can limit the impact of the current attack to democratic institutions and values in the U.S.

Although the U.S. suffered a worrying decline of institutional strength, its non-political institutions are reacting and we witness a phase of institutional resistance. In a few 
words, while the Trump administration represents an unprecedented menace to political oppositors, independent institutions are fighting back in order to stand up for democracy whenever it is undermined or in danger.

Finally, after the first 100 days of his administration Trump blamed the Constitution judging it as: "an archaic system. . . It's really a bad thing for the country." Some dangerous scenarios lie behind this veiled threat to the fundamental document of democracy in the U.S. and the basic symbol of the American creed. Indeed, despite the critics to the U.S. constitution, it is quite uncommon that a president attack, also indirectly, the constitution. However, in case of an explicit attack against the constitution and the integrity of the American institutions, the U.S. democracy would resist quite easily and its constitutional architecture would continue to exist untouched. Constitutional rules in the U.S. cannot be changed on a presidential whim, nor by a majority in Congress, nor by the executive and legislative branches working in concert. In other words, the American Constitution protects its democracy from waves of anti-politics because its core principles remain intact. Indeed, the last word on amendment proposals is held by the states, and a qualified three-quarters majority is required in order to approve them. This explains why only 27 constitutional amendments have been approved since 1789. Thus, even though 32 states are controlled by Republican majorities, it is not enough to dismantle constitutional guarantees or revoke rights and freedoms.

\section{Conclusion}

With this in mind, we believe that Trump's America will have a different story to tell than those of other democracies in which constitutional guarantees have been attacked and weakened by populist leaders in government, as is currently the case in Hungary, where electoral consensus, a political majority and referendums have been used to implement and reforms that have led to a centralisation of power. Unless something unforeseen takes place, American democracy will overcome its T-test (meaning Trumptest).

And if it does, it will be among the few that have been able to resist attacks of antipolitics and survive the crisis, further demonstrating the capacity of American democracy to adapt to the challenges of its times while preserving its identity.

The recurrent abuse of power showed by the Index of institutional strength could be exactly a case of little-noticed and incremental steps mentioned by Robert Mickey, Steven Levitsky and Lucan Ahmad Way:

"If democratic backsliding were to occur in the United States, it would not take the form of a coup d'état; there would be no declaration of martial law or imposition of single party rule. Rather, the experience of most contemporary autocracies suggests that it would take place through a series of little-noticed, incremental steps, most of which are legal and many of which appear innocuous. Taken together, however, they would tilt the playing field in favor of the ruling party."18

41 As a result, we embrace a different point of view highlighting that the crux of the problem is not merely if the President uses the power in an illiberal way, rather than which level of institutional defense exists in these democracies and how the Members of the United States Congress behave. 

when antidemocratic leaders win the elections, open the doors of the institutions and gain the political power to govern? Will they be enough strong to resist to these attacks and eventually limit the power of the President? Will the institutions protect their liberal and democratic political identity?

In this night of democracy, the most important unknown remains the future health of American democracy, as its political model and priorities have still a worldwide influence on other societies. Contrary to most of the alarms of those ones who cry wolf on democracy in America as a hopeless case, we argue that the U.S. will be able to succeed in coping with the current menace as its democratic strength depends in considerable measure on the integrity of its institutions and constitutional order. Both these aspects will be barely manipulated, and the effects of this administration despite all the risks it entails - will not damage in a complete and irreversible way the institutional integrity of the American democracy and its chances to thrive again.

\section{BIBLIOGRAPHY}

Code of Federal Regulations of the Federal Communications Commission.

Epstein, David and Sharyn O'Halloran. Delegating Powers: A Transaction Cost Politics Approach to Policy Making under Separate Powers, Cambridge University Press, 1999.

Fukuyama, Francis. Checks and Balances, The American interest, 2017.

Huber, John D.. The Vote of Confidence in Parliamentary Democracies. The American Political Science Review, Volume 90, No. 2, 1996.

Laver, Michael and Kenneth A. Shepsle. Making and Breaking Governments: Cabinets and Legislatures in Parliamentary Democracies, Cambridge University Press, 1996.

Levinson, Daryl J., and Richard H. Pildes. Separation of Parties, Not Powers, Harvard Law Review, 2006.

Levitsky, Steven. Memo prepared for "Global Populisms as a Threat to Democracy" conference, Stanford University, 2017.

Madison, James. Spirit of Governments, National Gazette, February 18, 1792.

Mickey, Robert. Levitsky, Steven and Lucan Ahmad Way. Is America Still Safe for Democracy? Why the United States is in Danger of Backsliding. Foreign Affairs, 2017.

Morlino, Leonardo and Wojciech Sadurski. Democratization and the European Union: Comparing Central and Eastern European Post-communist Countries, Routledge, 2010.

Przeworski, Adam. Democracy and the Limits of Self-Government, New York University Press, 2010.

Ragsdale, Lyn. Vital Statistics on the Presidency, CQ Press (various editions).

Rules of the Supreme Court of the United States, 2017.

Sartori, Giovanni. Comparative Constitutional Engineering, NYU Press, 1997. 
Stanley, Harold and Richard Niemi. Vital Statistics on American Politics, CQ Press (various editions).

The Constitution of the United States of America, 1787.

The U.S. National Archives and Records Administration, Federal Register: laws.

Tocqueville, Alexis (de). Democracy in America, 1835.

United States Public Laws $103^{\text {rd }}$ Congress, N. 419, Civil Right Commission Amendments Act, October $25,1994$.

United States Public Laws $92^{\text {nd }}$ Congress, N. 225, Federal Election Campaign Act, enacted February 7, 1972.

Vile, M. J. C.. Constitutionalism and the Separation of Powers, Liberty Fund, 1962.

Wolfgang, Merkel. Is There a Crisis of Democracy?. Democratic Theory, Volume 1, Issue 2, 2014

Woolley, John T. and Gerhard Peters. "House and Senate Concurrence with Presidents." in The American Presidency Project, University of California, 1999-2016: http://www.presidency.ucsb.edu/ data/concurrence.php.

\section{NOTES}

1. Merkel Wolfgang, Is There a Crisis of Democracy?, Democratic Theory Volume 1, Issue 2, 2014, p. 11.

2. Tocqueville Alexis (de), Democracy in America, 1835.

3. Adam Przeworski, Democracy and the Limits of Self-Government, New York University Press, 2010, p. xiv.

4. James Madison, Spirit of Governments, National Gazette, February 18, 1792.

5. Daryl J. Levinson and Richard H. Pildes, Separation of Parties, Not Powers, Harvard Law Review, Harvard Public Law Working Paper No. 13, 2006, p. 12.

6. Francis Fukuyama, Checks and Balances, The American interest, Oct. 18, 2017.

7. Leonardo Morlino and Wojciech Sadurski, Democratization and the European Union: Comparing Central and Eastern European Post-communist Countries, Routledge, 2010, p. 6.

8. Source: John T. Woolley and Gerhard Peters, House and Senate Concurrence with Presidents, The American Presidency Project, University of California, 1999-2016: http://www.presidency.ucsb.edu/data/concurrence.php. For other sources: Lyn Ragsdale, Vital Statistics on the Presidency, CQ Press (various editions). Harold Stanley and Richard Niemi, Vital Statistics on American Politics, CQ Press (various editions). Congressional Quarterly Weekly Report (various editions).

9. M. J. C. Vile, Constitutionalism and the Separation of Powers, Indianapolis: Liberty Fund, (1962) 2012, p. 18.

10. David Epstein and Sharyn O'Halloran, Delegating Powers: A Transaction Cost Politics Approach to Policy Making under Separate Powers, Cambridge University Press, 1999, p. 154-155. 11. John D. Huber, The Vote of Confidence in Parliamentary Democracies, The American Political Science Review, Vol. 90, No. 2, 1996, p. 268.

12. Michael Laver and Kenneth A. Shepsle, Making and Breaking Governments: Cabinets and Legislatures in Parliamentary Democracies, Cambridge University Press, 1996, p. 3.

13. Giovanni Sartori, Comparative Constitutional Engineering, NYU Press, 1997, p. 166.

14. Francis Fukuyama, Checks and Balances, The American interest, Oct. 18, 2017.

15. James Madison, The Federalist Paper N. 48: From the New York Packet, February 1, 1788. 
16. Thomas Friedman, "Whatever Trump is hiding is hurting all of us now," New York Times, February 18, 2018.

17. Steven Levitsky, memo prepared for "Global Populisms as a Threat to Democracy" conference, Stanford University, November 2017, p. 4.

18. Steven Levitsky, memo prepared for "Global Populisms as a Threat to Democracy" conference, Stanford University, November 2017, p. 4.

\section{ABSTRACTS}

The article describes a new theoretical framework and empirical method to understand the power of parties within the U.S. Government. Political parties are not simply critical means by which citizens participate in their government, but also foundational to a pluralist political society and play an active role in defending the constitutional principles of liberal institutions and democracy.

The first part of the article provides an overall glance of the dimensions used for observing the political power during democratic crises. Then, it is concerned with the identification of some "compelling" dimensions of political behavior of parties, and an empirical analysis of the changes occurred in the American institutions conducted in a long-term perspective of the last 25 years. Indeed, the second part accurately refers to the degree of which its political balances, institutional guarantees and constitutional design provide effective defense to democracy. Finally, these results invite us to watch at the current troubles with a moderate share of realism on the future capacity of democracy in the U.S. to survive.

\section{INDEX}

Keywords: political power, U.S. Government, institutions, democracy

\section{AUTHOR}

\section{MATTEO LARUFFA}

Matteo holds a PhD from LUISS University. Visiting Fellow at Harvard University in 2017. He is also member of the Council for European Studies at Columbia University since 2014. Matteo taught a course at Freie Universität of Berlin in 2018 and spent a semester at Humboldt Universitat zu Berlin as researcher. In the last years he has given lectures and presented papers in several worldwide institutions, such as universities in the U.S.A., Italy, Belgium, Germany, Hungary, the Netherlands, Spain, France, Finland and U.K. He speaks fluently English, Spanish and Italian. 